\title{
Analysis and Suggestions on the Factors of Income Gap
}

\author{
Yuan Gao \\ Department of Information Management, School of Business, Lingnan Normal University, Zhanjiang, China \\ Email address: \\ Brittany_gao@163.com

\section{To cite this article:} \\ Yuan Gao. Analysis and Suggestions on the Factors of Income Gap. Advances in Sciences and Humanities. Vol. 5, No. 2, 2019, pp. 65-69. \\ doi: 10.11648/j.ash.20190502.14
}

Received: May 5, 2019; Accepted: June 12, 2019; Published: June 25, 2019

\begin{abstract}
Income gap reflects the imbalance of economic development in a region. Excessive income gap will affect social instability, aggravate social contradictions and conflicts, thus hindering social progress and development. Reasonable narrowing of income gap is conducive to optimizing the allocation of resources and improving social production efficiency. Guangdong Province has a high per capita income level in China. With the further development of Guangdong's economy, the income gap has changed to a certain extent, and this issue still attracts much attention. By consulting the basic data obtained from the Guangdong Yearbook in 2018, the Gini coefficient of Guangdong Province in 2018 is 0.335 , which is basically reasonable, but it has not reached a relatively average level. The gap between GDP and per capita GDP of the four regions in Guangdong Province (Pearl River Delta, East Wing, West Wing, East Guangdong, West Guangdong, North Guangdong) is still large. By analyzing the factors of natural conditions, calculating the proportion of three industries and other factors, this paper explores the reasons for the formation of income gap, and puts forward some suggestions to narrow the gap from the aspects of optimizing industrial structure, adjusting income distribution and differentiating taxation, and finally draws a conclusion.
\end{abstract}

Keywords: Gini Coefficient, Consumption Gap, Income Gap

\section{Introduction}

Income gap has been a hot issue in recent years. Reasonable opening of income gap is conducive to the optimal allocation of resources and the improvement of social production efficiency. [1] However, too large income gap will also affect social instability and hinder social development. For Guangdong Province, which has a relatively high per capita income level in the country, the income gap within it is also very wide, which will inevitably hinder the future economic development of Guangdong Province. Therefore, this paper discusses the causes of the income gap in Guangdong Province and the corresponding decision-making issues.

\section{General Situation of Income Gap}

Taking into account the regional productivity level, geographical location and the integrity of the current administrative region of Guangdong Province, and taking into account the division of Guangdong Province in the statistical yearbook of Guangdong Province, Guangdong Province is divided into four parts according to its geographical region:
Pearl River Delta (Guangzhou, Shenzhen, Zhuhai, Foshan, Jiangmen, Dongguan, Zhongshan, Huizhou, Zhaoqing), Eastern Region (Shantou). Shanwei, Chaozhou and Jieyang, Western Region (Zhanjiang, Maoming and Yangjiang), Mountainous Region (Shaoguan, Heyuan, Meizhou, Qingyuan and Yunfu).

\subsection{The Current Situation of Income Gap in Guangdong Province}

(1) Gini coefficient increased. Gini coefficient, or translated Gini coefficient, is an index to judge the fairness of income distribution defined by Italian economist Gini in the early 20th century. It is a proportional value, between 0 and 1 . It is an important analysis index used to comprehensively investigate the difference of income distribution among residents in the world. According to the relevant United Nations organizations, below 0.2 means absolute average income; 0.2-0.3 means relatively average; $0.3-0.4$ means relatively reasonable; 0.4-0.5 means a large income gap; more than 0.5 means a wide income gap. According to the Gini coefficient calculation formula put forward by Zhang Jianhua, School of Economics and Trade, Shanxi Agricultural University, and the table of 
"disposable income per capita of all permanent residents grouped by five equal parts of income" in the statistical yearbook of Guangdong Province in 2018, the Gini coefficient of Guangdong Province in 2017 is 0.335 . Although it is still in a reasonable area, it has not reached a relatively average level.
(2) Expanding the consumption gap. The income level determines the consumption level, so the widening of the income gap will inevitably lead to the widening of the consumption level gap.

Table 1. Fixed-base Consumer Price Indices by Category and by regions of Guangdong 2017 (2015year=100)

\begin{tabular}{|c|c|c|c|c|c|c|c|}
\hline City & Total Index & City & Total Index & City & Total Index & City & Total Index \\
\hline Guangzhou & 113.66 & Shenzhen & 118.42 & Zhuhai & 120.85 & Shantou & 112.53 \\
\hline Foshan & 117.80 & Shaoguan & 118.31 & Heyuan & 122.54 & Meizhou & 120.78 \\
\hline Huizhou & 122.44 & Shanwei & 116.52 & Dongguan & 112.06 & Zhongshan & 123.86 \\
\hline Jiangmen & 124.96 & Yangjiang & 120.91 & Zhanjiang & 117.09 & Maoming & 114.49 \\
\hline Zhaoqing & 115.79 & Qingyuan & 120.80 & Chaozhou & 109.61 & Jieyang & 110.94 \\
\hline Yunfu & 114.32 & & & & & & \\
\hline
\end{tabular}

Data source: Estimation of Guangdong Statistical Yearbook 2018

From the data in table 1, it can be seen that there are great differences in the consumer index of residents, with the Pearl River Delta region as the highest, while other regions are relatively poor. That is to say, the consumption level in the Pearl River Delta region is still higher than that in other regions, which shows that the consumption gap is widening year by year.

\subsection{The Performance of Excessive Income Gap}

According to the data provided by the statistical yearbook of Guangdong Province, the GDP output and per capita GDP of the whole province and four regions in 2017 are obtained through analysis, calculation and collation, as shown in Table 2. [2]

Table 2. GDP and Per Capita GDP by regions of Guangdong 2017.

\begin{tabular}{|c|c|c|c|c|c|}
\hline \multirow[b]{2}{*}{ Area } & \multicolumn{3}{|l|}{ GDP } & \multicolumn{2}{|l|}{ Average GDP } \\
\hline & $\begin{array}{l}\text { Amount of } \\
\text { money(100million yuan) }\end{array}$ & $\begin{array}{l}\text { The proportion in the } \\
\text { province }(\%)\end{array}$ & $\begin{array}{l}\text { Absolute disparity }(100 \text { million } \\
\text { yuan) }\end{array}$ & $\begin{array}{l}\text { Amount of } \\
\text { money (yuan) }\end{array}$ & $\begin{array}{l}\text { Absolute } \\
\text { disparity (yuan) }\end{array}$ \\
\hline Whole province & 89705.23 & 100 & - & 80932 & - \\
\hline Pearl River Delta & 75710.14 & 84.40 & - & 124564 & - \\
\hline Eastern Region & 6202.54 & 6.91 & -69507.60 & 35844 & -88720 \\
\hline Western Region & 7022.40 & 7.83 & -68687.74 & 43922 & -80642 \\
\hline
\end{tabular}

Data source: Estimation of Guangdong Statistical Yearbook 2018

From the per capita GDP figures, the income gap is obvious. The per capita income in the Pearl River Delta region has exceeded 120,000 yuan, while the per capita income in Meizhou, Qingyuan and other mountainous areas is only 33,000 yuan. Let's look at the eastern and Western wings of the middle reaches, whose per capita income is only 35,000 yuan and 43,000 yuan, which is only one fourth of that of the Pearl River Delta.

\section{Reasons for the Income Gap}

\subsection{Differences in Natural Conditions and Economic Basis Among Regions}

Physical geographical conditions are one of the important factors in economic development. The Pearl River Delta is located in the large alluvial plain of the Pearl River Estuary. Guangzhou, the provincial capital, has convenient transportation. Its developed transportation facilities, such as roads, railways and airports, have laid the foundation for its economic development [3]. In addition, adjacent to Hong Kong and Macao, a large number of overseas investment and freight gradually from Hong Kong and Macao to the Mainland, and the Pearl River Delta region has become a gateway to the Mainland. Most of the mountainous areas in eastern, western and Northern Guangdong and the eastern and Western flanks of Guangdong are composed of rolling mountains and hills. Some areas are located in limestone areas where living conditions are extremely poor [4]. A few areas are located in the undeveloped coastal alluvial plains with complex terrain, inconvenient traffic and poor information. Small-scale peasant economy or natural economy have long been the main form of landforms. The conditions for development are quite difficult if we want to receive confinement. Therefore, the Pearl River Delta region relies on its advantageous natural conditions to develop processing industry and some modern electronic industries earlier, so that its economic development shows its superiority in the early stage of reform and opening up. In addition, the recent scientific and technological progress has made the GDP output value of the Pearl River Delta region, which already has a better economic base, far higher than that of other regions, accounting for almost $84.4 \%$ of the total GDP of the province [5]. 


\subsection{There Are Differences in Industrial Structure}

Table 3. The structure and GDP by three industries of regions of Guangdong.

\begin{tabular}{|c|c|c|c|c|c|c|}
\hline & \multicolumn{2}{|l|}{ Primary Industry } & \multicolumn{2}{|c|}{ Secondary Industry } & \multicolumn{2}{|l|}{ Tertiary Industry } \\
\hline & $\begin{array}{l}\text { GDP } \\
\text { (100million yuan) }\end{array}$ & $\begin{array}{l}\text { Percentage of } \\
\text { GDP }(\%)\end{array}$ & $\begin{array}{l}\text { GDP (100million } \\
\text { yuan) }\end{array}$ & $\begin{array}{l}\text { Percentage of GDP } \\
(\%)\end{array}$ & $\begin{array}{l}\text { GDP } \\
\text { (100million yuan) }\end{array}$ & $\begin{array}{l}\text { Percentage of } \\
\text { GDP }(\%)\end{array}$ \\
\hline Whole province & 3611.44 & 4.03 & 38008.06 & 42.37 & 48085.73 & 53.60 \\
\hline Pearl River Delta & 1181.53 & 1.56 & 31542.82 & 41.66 & 42985.8 & 56.78 \\
\hline Eastern Region & 455.36 & 7.34 & 3115.66 & 50.23 & 2631.53 & 42.43 \\
\hline Western Region & 1172.86 & 16.70 & 2674.7 & 38.09 & 3174.84 & 45.21 \\
\hline Mountainous Region & 800.36 & 14.45 & 1973.38 & 35.62 & 2766.01 & 49.93 \\
\hline
\end{tabular}

Data source: Estimation of Guangdong Statistical Yearbook 2018

From the analysis of Table 3, the output value of the primary industry in the province is 361.144 billion yuan, accounting for $4.03 \%$ of GDP. The output value of the primary industry in the Pearl River Delta region is 118.153 billion yuan, accounting for only $1.56 \%$ of the GDP of the whole Pearl River Delta region, while the other three regions have relatively high proportions [6]. The proportion of the difference between the second and the third industries in each region is relatively weak compared with the first industry. Therefore, from the perspective of the composition of the three industries, there are big differences in the four regions. The industries that can increase the proportion of GDP are mainly the second and the third industries. Therefore, the Pearl River Delta region has occupied a certain advantage in terms of industrial structure.

\subsection{Other Aspects}

The reasons that affect the income gap are not only the differences in natural conditions and industrial structure, but also many other factors, such as people's ideas and cultural connotations, the differences in preferential policies between regions, the behavior of local governments, the differences in economic systems and so on. [7]

The Pearl River Delta region has obvious advantages in terms of personnel quality, preferential policies given by the state, and economic system. [8] Therefore, it is not difficult to explain that the GDP output value of the Pearl River Delta region is much higher than that of other regions, and it has become the representative region of Guangdong Province.

\section{Countermeasures for Narrowing the Income Gap}

\subsection{Speed up the Pace of Industrial Restructuring and Optimize the Economic Structure}

First, in the Pearl River Delta region, we should adhere to the new road of industrialization, optimize the industrial layout, build a good high-tech industrial belt in the Pearl River Delta, build a coastal petrochemical industrial belt and a coastal iron and steel industrial base, accelerate the formation of industrial transfer belt around the Pearl River Delta, and promote industrial upgrading in underdeveloped areas. [9] At the same time, the Pearl River Delta should strengthen regional cooperation with the eastern and Western wings and mountainous areas, strengthen cooperation with Hong Kong and Macao, speed up the economic development of the Greater Pearl River Delta, and promote regional cooperation and development of the Pan-Pearl River Delta in order to form a reasonable industrial division and benign interaction among regions.

Secondly, we should take the development of resource-based and characteristic industries as a breakthrough to promote the leapfrog development of mountainous areas and Eastern and Western wings. First, mountainous areas should give full play to their own advantages, increase investment and actively promote industrialization. [10] We should select and develop the characteristic pillar industries, cultivate the dominant industries, enterprises and products with strong market economy, and form the industrial structure with county characteristics. Second, we should strengthen the dominant position of industries on both sides of the East and the west, give full play to the advantages of seafront location and resources, and focus on developing the heavy chemical industry, characteristic industries and supporting industries on both sides of the East and the west. Rich tourism resources, develop characteristic tourism, build characteristic tourism brand, and increase new advantages of tourism. [11] Third, we should strengthen regional exchanges and cooperation, with economic parks as the focus of regional exchanges and cooperation, relying on industrial clusters and professional towns and other carriers, guide enterprises into the parks, promote industrial agglomeration development, accelerate industrialization process, undertake industrial transfer, and realize the transfer of industries from the Pearl River Delta to other three regions through the construction of economic parks.

\subsection{Adjusting the Relationship of Income Distribution and Expanding the Proportion of Middle-Income People}

At present, the proportion of high, middle and low income in Guangdong Province is pyramid, and the more reasonable income distribution should be "olive". Therefore, by adjusting the high-income group, we should guarantee the basic life of the low-income group and expand the number of the middle-income group in society.

\subsection{Implementing Differential Regional Tax Policies}

Implementing inclined regional preferential policies in 
relatively backward areas is a powerful measure to narrow the regional economic gap [12]. Tax preferential policies can be implemented in relatively backward areas of Guangdong Province, which can improve the return on capital in a disguised way. It can not only attract some inflows of foreign capital, but also curb the outflow of local capital and promote local economic development. Of course, the regional tax preferential policy is not omnipotent, it can only gradually and step by step with the gradual improvement of regional economic policy, can only promote the balanced development of regional economy reasonably, limited and moderately. Therefore, in terms of development thinking, we must adhere to reasonable and appropriate regional tax preferential policies, effectively handle the boundaries of "quantity" and "degree", and gradually narrow the gap between regional economic development [13].

\subsection{Regulate the Relationship Between Local Governments and Enterprises in Accordance with the Law, So That Enterprises Can Become the Real Subject of Market Economy}

In the market economy, enterprises are the main economic subjects, and the main role of local governments is to provide public goods and services, create an economic and social environment suitable for the needs of their business activities, and supervise the legitimacy of business operations [14]. However, local governments often intervene directly in the economic activities of enterprises by means of administration and economy from the local interests. Enterprises are only the dependencies of local governments, not the real market economy subjects. This weakens the enterprises in developed areas to invest in underdeveloped areas and allocate resources according to their comparative advantages. Therefore, speeding up the system reform of separating government from enterprise, standardizing the relationship between local government and enterprise according to law, and making enterprises truly become the main body of market economy are essential to narrow the regional economic gap.

\subsection{Reconstruct the Enterprise Organization and Industrial Organization System of Reasonable Division of Labor}

The difference of enterprise property right system also shows that the form of enterprise organization is different, and the innovation of enterprise organization is of great significance to the development of regional economy. The economic prosperity of the Pearl River Delta is related to the organizational innovation of the external migrant enterprises, that is, the entry of a large number of Taiwanese, Hong Kong, Macao and overseas Chinese capital. There is no difference between eastern Guangdong and the Pearl River Delta in this respect [15]. The problem lies in the small scale of enterprises in eastern Guangdong, the low standard of operation of enterprises and the low degree of industrial cooperation between enterprises. A large number of decentralized, atomic enterprises are in separate battles, and the professional division and cooperation system between enterprises in the same industry has not been formed, and even fierce vicious competition is often launched among them. Some towns have developed the production of rice cookers. However, in one town, there are hundreds of enterprises producing rice cookers, but there is still a lack of well-known brand enterprises in the whole country [16]. Therefore, we should accelerate the accumulation of factors of production, really combine the enterprises with complementary advantages, form the development of innovative leading ability and the system of enterprises and centers and satellite factories. Through the diffusion effect and the principle of professional division of labor, we should form a loose enterprise network or enterprise consortium with different functions, promote the development of small and medium-sized enterprises, and promote the development of these areas.

\section{Conclusions}

The main factor of income gap in Guangdong Province comes from the original economic base and natural resources, which directly leads to the Matthew effect in the distribution of the three industrial structures. We can improve or narrow the income gap by adjusting the industrial structure, adjusting income distribution, differentiating tax policies, regulating the relationship between local governments and enterprises, and reconstructing the organizational system of enterprises.

\section{References}

[1] Zhang Jie. Regional Economic Differences and Countermeasures in Guangdong Province [D]. Jinan University. 2002.

[2] Guangdong Statistical Bureau. Guangdong Statistical Yearbook 2018 [Z]. 2018.

[3] Samuelson P A. An Exact Consumption-loan Model of Interest With or Without the Social Contrivance of Money [J]. Journal of Political Economy, 1958, (66).

[4] Xavier X, SALA-I. A Positive Theory of Social Security [J]. Journal of Economic Growth, 1996, (2).

[5] Diamond P A A Framework for Social Security Analysis [J]. Journal of Public Economic, 1997, (8).

[6] Jeffrey B. Liebman. Redstribution in the Current U.S. Social Security System [J]. NBER Working Paper 2005, (12).

[7] Andres, J., O. Arce. Banking competion, housingprices and macroeconomic stability, Economic Journal, 2012.

[8] Calvo G A. Staggered prices in a utility-maximizing framework. Journal of monetary Economics, 1983, 12 (3).

[9] Chari, Kehoe. Optimal fiscal and monetary policy, in: Taylor and Woodford, eds. Handbook of Macroeconomics, 1999.

[10] Christiano, L., R. Motto, M. Rostagno. Financial factors in economic fluctuations, European Central Bank Working paper, 2010 .

[11] Davis, S, K. X. D. Huang. Optimal monetary policy under financial sector risk, 2013. 
[12] Frank Smets, Rafael Wouters. Shocks and Frictions in US Business Cycles: A Bayesian DSGE Approach. American Economic Review, 2007, 97 (3).

[13] Gertler, M., P. Karadi. Amodel of unconventional monetary policy, Journal of Monetary Economics, 2011, 58 (1).

[14] Gertler, M., N. Kiyotaki. Financial intermediation and credit policy in business cycle analysis, in: B. Friedman\& M.
Woodford (ed), 2010, Handbook of Monetary Economics, vol.3A.

[15] Zhang, W. L. China's Monetary Policy: Quantity versus Price Rules, Journal of Macroeconomics, 2009, 31 (3).

[16] Chen Binkai, Lin Yifu. Development Strategy, Urbanization and China's Urban-Rural Income Gap [J]. Chinese Social Sciences, 2013 (4). 